\title{
Effect of various carbohydrate additives on peroxide formation in fat for confectionery production
}

\author{
V. Vītola \\ Joint stock company "Laima", \\ Miera Street 41-6, Riga, LV-1001, Latvia \\ E-mail:vineta.vitola.lv@gmail.com
}

B. Ozola

Latvia University of Agriculture,

Liela Street 2, Jelgava, LV-3001, Latvia

E-mail: baiba.ozola@llu.lv

cross $^{\text {ref }}$ http://dx.doi.org/10.5755/j01.ct.68.1.18879

Received 11 November 2016; Accepted 3 January 2017

A lot of ingredients used for food may have their own antioxidant activity. For this reason, it is necessary to explore the effect of natural antioxidants and non-specific antioxidants of some confectionery ingredients for the stabilization of food products against the formation of peroxides.

The aim of the study was to verify the effect of some carbohydrates in preventing the formation of peroxides in fat for the confectionery production and to prove that the quality and shelf-life of confectionery products are affected by ingredients used in the compositions of confectionery products and by compounds that are formed in their interaction.

Butter was used as the basic ingredient to study the fat stability. The effect of carbohydrates used in confectionery and their interaction with butter was examined, and the peroxides were determined. The effect of vanillin in facilitating or preventing the above-mentioned interaction was also determined.

Peroxides were determined by means of the standard LVS EN ISO 3960:2010.

It was established that practically all carbohydrates decreased the formation of peroxides in the samples. The quantity of peroxides in butter with $30 \%$ of sucrose was by $10.7 \%$ lower, with $30 \%$ of glucose - by $41.3 \%$ lower comparing to butter without additives after the samples had been stored for 30 days at $28 \pm 2{ }^{\circ} \mathrm{C}$. The most effective after 30 days of storage was sorbitol which decreased the formation of peroxides by $65.3 \%$. The same activity was also established for vanillin. Its antioxidant activity was similar to the activity of sugars, and therefore their summary activity reduces in confectionery products. It is established that the activity of sugars is quite temporary, and with increasing the quantity of peroxides in the product it decreases or completely disappears.

Key words: food ingredients, quality, peroxides, carbohydrates, vanillin.

\section{Introduction}

The quality of food products is determined by several factors such as ingredients, production process and storage conditions of the ready-made products, and also by interaction of these factors. Yet, the most essential factor is the quality of ingredients and the side effect of biologically active compounds contained by the ingredients.

One of the undesirable and unhealthy compounds in food products can be peroxides which are formed during the oxidation of fats [1, 2]. Antioxidants are added to products to prevent the formation of peroxides, but a lot of products used for food may have their own antioxidant activity. The food categories containing the highest antioxidant contents were spices and herbs, nuts and seeds, chocolate and sweets, vegetables and vegetable products, ready-to-eat cereals, desserts and cakes, and berry products [3].

The activity of the antioxidantive background depends on the type of the effect of the biologically active compounds in food products [4, 5]. Since this activity can be summed up (different types of antioxidants) or it can even stimulate the formation of peroxides, it is very likely to occur in confectionery due to a wide variety of ingredients, int. al. natural sweet stuffs and flavour regulators. The total antioxidant capacity is formed by compounds with the first, the second and the third type of antioxidants - antioxidant enzymes, chainbreaking antioxidants, and transition metal binding compounds [6] which can affect the shelf-life of the products. 
It is necessary to explore the effect of natural antioxidants and non-specific antioxidants of some confectionery ingredients for the stabilization of food products against the formation of peroxides.

Butter was used to carry out the studies as it is not only widely used in confectionery but also contains a wide variety of milk fats and other bioactive compound additives $[7,8]$.

The activity of carbohydrates used in confectionery and their interaction with fat and the effect of the widely used flavouring vanillin and water to stimulate or to prevent the abovementioned interaction were determined during the studies. The activity of the possible oxidation products of carbohydrates - glucuronic acid and gluconic acid - which are likely to be formed during oxidation was erified.

The novelty of the paper: evaluated the effect of carbohydrates on fat stability and their role in assuring quality.

\section{Materials and methods}

The object of the study was ingredients used in confectionery products - carbohydrates, lipids and flavourings.

Carbohydrates. The following carbohydrates are used: monosaccharides (anhydrous glucose and fructose), disaccharides (sucrose, lactose), polyols (sorbitol, maltitol and glucose syrup DE40).

Additives. Crystallline vanillin powder and distilled water are used as additives.

The other ingredients. Derivation of carbohydrates: gluconic acid, glucuronic acid. D glucuronic acid, assay $\geq 97 \%(\mathrm{~T})$; D - gluconic acid, 45-50 wt.\% solution in water are used as the oxidation products of carbohydrates.

Lipids. The oxidative stability of the main confectionary ingredients was tested making trials with butter. Butter is a "water-in-oil" emulsion and therefore is considered to be the most effective material for carrying out the experiments. Sweet cream butter (producer - SC Riga dairy) with the fat content of $82.5 \%$ and moisture content of $16 \%$ was used for the experiments.

The following additives were added to butter: $0.2 \%, 1.0 \%, 2.0 \%, 10 \%, 30 \%$ of glucose syrup (40 DE); $30 \%$ of sucrose, glucose, fructose, lactose, sorbitol, maltitol; $0.05 \%, 0.2 \%, 0.5 \%$ of vanillin; composition $-0.2 \%$ of vanillin and $30 \%$ of glucose; composition $-0.2 \%$ of vanillin, $30 \%$ of glucose and $10 \%$ of water; $0.5 \%$ of gluconic acid and $0.5 \%$ of glucuronic acid.

At the beginning of the experiments, the amount of peroxides in butter and in butter with additives was determined.

All samples were prepared in the same conditions and mixed for one minute. Mixed samples were put into Petri dishes and kept in an incubator. After that, the quantity of peroxides was determined. The peroxides value was determined according to the LVS EN ISO 3960:2010 standard [9].

The peroxide value was tested in butter with additives after 30 and 90 days of incubation at $28 \pm$ $2{ }^{\circ} \mathrm{C}$. The chosen parameters correspond to accelerated food shelf-life testing in the confectionery industry.

The acquired quantities of peroxide were compared with the control sample - butter without additives.

Analyses of peroxides were made at the Laboratory of Chemistry of the Faculty of Food Technology of the Latvia University of Agriculture. Analyses of glucuronic acid and gluconic acid were made at the Chemical Laboratory of the s/c "Palsgaard" in Denmark.

The statistical data analysis was used to analyze the differences among the samples and their oxidative stability during the accelerated food shelf-life testing. Data were analyzed by the onefactor dispersion analysis using the MS Excel and SPSS program package SPSS 11.0. All tests were regarded as statistically significant at $p<0.05$. Results were presented as a mean \pm standard deviation from five replicates of each experiment.

\section{Results and discussion}

In experiments, it was found that practically all carbohydrates retained confectionery quality by reducing the risk of peroxide formation in them.

It had been established before that mono-, di-, and polysaccharides additives could have an effect on the formation of peroxides in butter [10]. It was necessary to clarify the dependence of the peroxide value on the quantity of the carbohydrates added.

The formation of peroxides in butter was prevented starting from $1.0 \%$ of the glucose syrup additive when after 30 days of storage the content of peroxides was $0.52 \pm 0.01 \mathrm{mmol} / \mathrm{kg}(p<0.05)$ (Table 1) comparing to the control sample (butter without additive after storage) $-0.73 \pm 0.01 \mathrm{mmol} / \mathrm{kg}$. 
Table 1. Peroxide formation in butter with various concentrations of glucose syrup additive after 30 days of storage at $28 \pm 2{ }^{\circ} \mathrm{C}$

\begin{tabular}{|c|c|c|}
\hline Samples & $\begin{array}{c}\text { Peroxides, } \\
\mathrm{mmol} / \mathrm{kg}\end{array}$ & $\begin{array}{c}\text { Peroxides per control, } \\
\%\end{array}$ \\
\hline Butter after storage & $0.73 \pm 0.01(*)$ & 100 \\
\hline Butter with 0.2\% glucose syrup & $0.70 \pm 0.01$ & 71.23 \\
\hline Butter with 1.0\% glucose syrup & $0.52 \pm 0.01$ & 58.90 \\
\hline Butter with 2.0\% glucose syrup & $0.43 \pm 0.01$ & 47.95 \\
\hline Butter with 10.0\% glucose syrup & $0.35 \pm 0.01$ & 43.84 \\
\hline Butter with 30.0\% glucose syrup & $0.32 \pm 0.01$ & \\
\hline
\end{tabular}

*Peroxides in butter before storage $-0.43 \pm 0.01 \mathrm{mmol} / \mathrm{kg}$.

The experiments showed that various quantities of glucose syrup prevented the formation of peroxides in butter, and the peroxides decreased by adding more glucose syrup, which means that a higher concentration of glucose prevents the formation of peroxides. Experiments showed that $30 \%$ of a carbohydrate additive was the most effective level to compare peroxides per control (Table 1). In further experiments, the $30 \%$ carbohydrate additive was accepted as a standard, and it is the optimal sugar content in confectionery products.
The possible effect of carbohydrates can be explained by the presence of an aldehyde group which has a typical reducing effect on the reductive activity of a hydroxyl group $[4,11]$. We can find data on antioxidants in refined sugar in the researches that have been done in the USA [3] and data on the antioxidant activity of some phenolic compounds in the sugarcane juice [12].

Table 2 demonstrates how the formation of peroxides in butter is affected by different carbohydrate additives when storing butter at $28 \pm$ $2{ }^{\circ} \mathrm{C}$ for 30 to 90 days.

Table 2. Peroxide formation in butter with various carbohydrates and sweeteners after 30 and 90 days of storage at $28 \pm 2{ }^{\circ} \mathrm{C}$

\begin{tabular}{|c|c|c|}
\hline Samples & $\begin{array}{c}\text { Peroxides after 30 days, } \\
\mathrm{mmol} / \mathrm{kg}\end{array}$ & $\begin{array}{c}\text { Peroxides after 90 days, } \\
\mathrm{mmol} / \mathrm{kg}\end{array}$ \\
\hline Butter after storage & $0.75 \pm 0.02\left(^{*}\right)$ & $0.92 \pm 0.02(*)$ \\
\hline Butter with 30\% of glucose & $0.44 \pm 0.02$ & $1.29 \pm 0.02$ \\
\hline Butter with 30\% of fructose & $0.56 \pm 0.02$ & $0.99 \pm 0.03$ \\
\hline Butter with 30\% of lactose & $0.69 \pm 0.02$ & Moldy \\
\hline Butter with 30\% of sucrose & $0.67 \pm 0.02$ & $0.90 \pm 0.01$ \\
\hline Butter with 30\% of sorbitol & $0.26 \pm 0.01$ & $1.01 \pm 0.01$ \\
\hline Butter with 30\% of maltitol & $0.46 \pm 0.03$ & 0.03 \\
\hline
\end{tabular}

\footnotetext{
* Peroxides in butter before storage $-0.52 \pm 0.01 \mathrm{mmol} / \mathrm{kg}$.
}

The content of peroxides in butter containing a carbohydrate additive while it had been stored up to 30 days decreased, but after it had been stored for up to 90 days, this quantity increased as compared with the quantity of peroxides in the control sample (Table 2). A higher antioxidative effect after 30 days of storage was shown by sorbitol. In this sample, after 90 days the content of peroxides $(0.90 \pm 0.01 \mathrm{mmol} / \mathrm{kg})$ was the lowest as well as compared with the periods. Experiments showed that $30 \%$ of glucose decreased the formation of peroxides in butter after 30 days of storage, but after 90 days the amount of peroxides was increased as compared with the content of peroxides in the control. The content of peroxides after 90 days was increased in all samples excepted the sample with sorbitol. In the sample with sucrose it was the highest $(1.67 \pm 0.03 \mathrm{mmol} / \mathrm{kg})$.

The effect of carbohydrates depending on the temperature and storage time was decreased; this, in its turn, increased the content of peroxides.

The addition of lactose facilitated the growth of moulds in a sample stored for a long period of time (Table 2).

The formulae of confectionary products contain a range of other compounds in which molecules are more or less active functional groups. Vanillin was selected for testing.

Vanillin is very widely used in confectionery. The molecule of vanillin-4-hydroxy-3- 
methoxybenzaldehyde contains a group of aldehydes, the $\mathrm{OH}^{-}$group, and the compound has a weak acid reaction [13].

The results have shown that vanillin has some antioxidant activity. The most active was the $0.05-$
$0.2 \%$ additive of vanillin after it had been stored for 30 and 90 days at a temperature of $28 \pm 2{ }^{\circ} \mathrm{C}$ (Table 3), and between the two samples there was no significant difference $(p>0.05)$.

Table 3. Peroxide formation in butter and in compositions with vanillin after 30 and 90 days of storage at $28 \pm 2{ }^{\circ} \mathrm{C}$

\begin{tabular}{|c|c|c|}
\hline Samples & $\begin{array}{c}\text { Peroxides after 30 days, } \\
\mathrm{mmol} / \mathrm{kg}\end{array}$ & $\begin{array}{c}\text { Peroxides after 90 days, } \\
\mathrm{mmol} / \mathrm{kg}\end{array}$ \\
\hline Butter after storage & $0.49 \pm 0.01(*)$ & $0.57 \pm 0.01(*)$ \\
\hline Butter with 0.05\% of vanillin & $0.24 \pm 0.02$ & $0.32 \pm 0.01$ \\
\hline Butter with 0.2\% of vanillin & $0.25 \pm 0.02$ & $0.34 \pm 0.01$ \\
\hline Butter with 0.5\% of vanillin & $0.38 \pm 0.02$ & $0.51 \pm 0.02$ \\
\hline
\end{tabular}

*Peroxides in butter before storage $-0.38 \pm 0.01 \mathrm{mmol} / \mathrm{kg}$.

The compound additive of sugar and vanillin did not show the antioxidant effect (Table 4). The quantity of peroxides in butter containing the carbohydrate-vanillin additive while it had been stored until 30 days did not decrease, but after it had been stored for up to 90 days it increased as compared with the content of peroxides in the control. Comparing the data of Table 2 and
Table 3, we can see that the content of peroxides in a sample is affected by the added glucose.

In the classical theory, two similar active antioxidants cannot ensure a protective effect, especially if they are in great quantities [14]. We can conclude that vanillin has the antioxidant effect of the third group of antioxidants, and this obstructs the effect of carbohydrates.

Table 4. Peroxide formation in butter in compositions with vanillin after 30 and 90 days of storage at $28 \pm 2{ }^{\circ} \mathrm{C}$

\begin{tabular}{|l|c|c|}
\hline \multicolumn{1}{|c|}{ Samples } & $\begin{array}{c}\text { Peroxides after 30 days, } \\
\mathrm{mmol} / \mathrm{kg}\end{array}$ & $\begin{array}{c}\text { Peroxides after 90 days, } \\
\mathrm{mmol} / \mathrm{kg}\end{array}$ \\
\hline Butter after storage & $0.65 \pm 0.01(*)$ & $0.92 \pm 0.01\left(^{*}\right)$ \\
\hline Butter with 30\% glucose and 0.2\% vanillin & $0.69 \pm 0.01$ & $1.43 \pm 0.01$ \\
\hline $\begin{array}{l}\text { Butter with 10\% water, 30 \% glucose and } \\
0.2 \% \text { vanillin }\end{array}$ & $0.65 \pm 0.01$ & $0.98 \pm 0.01$ \\
\hline
\end{tabular}

*Peroxides in butter before storage $-0.47 \pm 0.02 \mathrm{mmol} / \mathrm{kg}$.

The glucose-vanillin additive did not prevent the formation of peroxides in the experimental samples in the presence of water (Table 4). We can conclude that the control and a sample with $30 \%$ glucose, $0.2 \%$ of vanillin and $10 \%$ water $(p>$ 0.05 ) have no significant differences.

Theoretically, carbohydrates can oxidize, and likely to be formed in this reaction are gluconic and glucuronic acids $[4,15,16]$. For this reason, we verified the antioxidant activity of gluconic and glucuronic acids.

Table 5 shows that the gluconic and glucuronic acids have not prevented the formation of peroxides. They have even increased the content of peroxides during the storage time up to 30 and 90 days as compared with the control sample - butter. This means that they have no antioxidant effect. That is why the experiments are not continued.

Table 5. Effect of carbohydrate oxidation products on the peroxide content in butter after 30 and 90 days of storage at $28 \pm 2{ }^{\circ} \mathrm{C}$

\begin{tabular}{|c|c|c|}
\hline Sample & $\begin{array}{c}\text { Peroxides after 30 days, } \\
\mathrm{mmol} / \mathrm{kg}\end{array}$ & $\begin{array}{c}\text { Peroxides after 90 days, } \\
\mathrm{mmol} / \mathrm{kg}\end{array}$ \\
\hline Butter after storage & $0.75 \pm 0.02(*)$ & $0.92 \pm 0.02$ \\
\hline Butter with 0.5\% gluconic acid & $1.51 \pm 0.02$ & $3.13 \pm 0.01$ \\
\hline Butter with 0.5\% glucuronic acid & $1.69 \pm 0.02$ & $3.43 \pm 0.01$ \\
\hline
\end{tabular}

*Peroxides in butter before storage $-52 \pm 0.01 \mathrm{mmol} / \mathrm{kg}$.

In this study, we have experimentally proved that the ingredients used for the production of confectionery products affect the quality of products by their mutual interaction. It is possible to prevent the formation of undesirable compounds 
and to prolong the shelf-life of products by changing the ingredients.

In order to improve and ensure the quality of confectionery products and to raise their nutritive value, when developing the confectionery product formulations it should be necessary to consider the following aspects:

1) to use the antioxidant effect of carbohydrates, taking into account that their effect is different and it can be affected by added additives;

2) before developing a recipe, it is necessary to verify the interaction of carbohydrates with the additives which have specific antioxidant properties and, if needed, to change the additives;

3 ) when changing carbohydrates or replacing them by sweeteners, it is necessary to verify their interaction with other components in the recipe;

4) the stability of fats against hydrolyses and oxidation must be verified at the temperatures that are specific in the technological process. It is also necessary to check the stability of fats in the presence of additives used in the recipe as well;

$5)$ when developing new recipes with a higher product biological value, it would be necessary to verify the amount and activity of bioactive compounds inside the ingredients and consider their interaction with other compounds during the industrial production process.

\section{Conclusions}

1. The carbohydrates and sweeteners under study, when added at the same concentrations, differently affect fat stability during storage time.

2. Carbohydrates do not prevent the activity of peroxides in products from the further process of oxidation.

3. The formation of peroxides in butter was prevented starting from $1 \%$ of the glucose syrup additive, and the activity increased upon adding more glucose syrup.

4. Vanillin was found to prevent the increase of peroxide levels in butter. Fat oxidation was effectively prevented when vanillin had been added in low concentrations $(0.05-0.2 \%)$.

5. Vanillin has an antioxidative effect, and this effect may be similar to the effect of sugar. The effect decreased when both components had been added together.

6. The results of the study allow to conclude that in confectionery products we cannot make any theoretical conclusions (due to the wide variety of ingredients) to prevent products from the formation of peroxides without exploring the effect and interaction of each individual ingredient.

\section{References}

1. Erickson M. C. Chemistry and function of phospholipids. In: Akoh C. C., Min D. B., eds. Food lipids chemistry, nutrition, and biotechnology. New York, Marcel Dekker, Inc., 2002. P. 39-55. https://doi.org/10.1201/9780203908815.ch2

2. Pokorny J. Production, separation and modification of phospholipids for use in food. In: Gustone F. D. ed. Modifying lipids for use in food. Cambrige, Woodhead Publishing Limited, 2006. P. 369-387. https://doi.org/10.1533/9781845691684.2.369

3. Halvorsen B. L., Carlsen M. H., Phillips K. M., Bøhn S. K., Holte K., Jacobs D. R., Blomhoff R. Content of redox-active compounds (i.e. antioxidants) in foods consumed in the United States // American Journal of Clinical Nutrition. 2006. Vol. 84. N 1. P. 95-135.

4. Campbell M. K., Farrell S. D. Biochemistry. Canada, Thomson Brooks Cole, 2009. 712 p.

5. Viuda-Martos M., Pérez-Álvarez J. A., Fernández-López J. Functional antioxidant foods. In: Bartosz G., ed. Food oxidants and antioxidants: chemical, biological, and functional properties. Boca Raton, CRC Press, 2013. P. 489-528.

6. Young I. S.,Wodside J. V. Antioxidants in health and diesease // Jornal Clinical Pathology. 2001. Vol. 54. N 3. P. 176-186. https://doi.org/10.1136/jcp.54.3.176

7. Ahn Y. J., Ganesan P., Kwak H. S. Composition, structure, and bioactive components in milk fat globule membrane // Korean Journal for Food Science of Animal Resources. 2011. Vol. 31. N 1. P. $1-8$. https://doi.org/10.5851/kosfa.2011.31.1.001

8. Shingfield K. J., Chilliard Y., Toivonen V., Kairenius P., Givens D. I. Transfatty acids and bioactive lipids in ruminant milk. In: Bosze Z., ed. Bioctive components of milk. New York, Springer, 2008. P. 3-66. https://doi.org/10.1007/978-0-387-74087-4_1

9. LVS EN ISO 3960:2010. Animal and vegetable fats and oils. Determination of peroxide.

10. Ozola B., Vìtola V., Kauliņš U. Antioxidant activity of mono-, di-, and oligosaccharides // Proceedings of international scientific practical conference new technologies in traditional foods. Jelgava, 2005. P. 165-166.

11. Galewska Z., Gogiel T., Malkowski A., Romanowicz L., Sobolewski K., Wolańska M. Carbohydrates. In: Białystok E., ed. Biochemistry workbook for students of the faculty of medicine and the faculty of health. Poland, Sciences Medical University of Białystok, 2013. P. 33-38.

12. Duarte-Almeida J. M., Novoa A. V., Linares A. F., Lajolo F. M., Genovese M. I. Antioxidant 
activity of phenolics compounds from sugar cane (Saccharum officinarum L.) juice // Plant Foods for Hum Nutr. 2006. Vol. 61. N 4. P. 187-192.

https://doi.org/10.1007/s11130-006-0032-6

13. Walton N. J., Mayer M. J., Narbad A. Vanillin // Phytochemistry. 2003. Vol. 63. N 5. P. 505-515. https://doi.org/10.1016/S0031-9422(03)00149-3

14. Scott G. Antioxidants in science, technology, medicine and nutrition. UK, Albion Publishing. 1997. $348 \mathrm{p}$. https://doi.org/10.1533/9780857099938

15. Pelley J. W. Formation of glucuronic acid and gluconic acid by oxidation of glucose. UK, Elsevier Health Sciences, 2011. 232 p.

16. Ramachandran S., Fontanille P., Pandey A., Larroche C. Gluconic acid: properties, applications and microbial production // Food Technol. Biotechnol. 2006. Vol. 44. N 2. P. 185195.
V. Vītola, B. Ozola

IVAIRIŲ ANGLIAVANDENIŲ PRIEDŲ İTAKA PEROKSIDŲ SUSIDARYMUI RIEBALUOSE, NAUDOJAMUOSE KONDITERIJOS PRODUKTŲ GAMYBAI

\section{S a n t r a u k a}

Daugelis maisto priedų, naudojamų maisto produktų gamyboje, gali pasižymèti antioksidaciniu aktyvumu. Dèl šios priežasties būtina ištirti natūralių ir nespecifinių antioksidantų, esančių kai kuriose sudedamosiose dalyse, naudojamose konditerijos produktams stabilizuoti, poveiki peroksidų susidarymui.

Darbo tikslas - įvertinti kai kurių angliavandenių inhibicini poveiki peroksidų susidarymui riebaluose, naudojamuose konditerijos produktų gamybai. Riebalų stabilumas buvo vertintas, naudojant sviestą kaip bazinị komponentą jam sąveikaujant su angliavandenių priedais. Papildomai buvo vertinta vanilino itaka peroksidų susidarymui riebalų ir angliavandenių mėginiuose. Peroksidu kiekis nustatytas pagal LVS EN ISO 3960:2010 pateiktą metodiką.

Nustatyta, kad praktiškai visi angliavandeniai mažino peroksidų susidarymą tirtuose mėginiuose. Peroksidų kiekis svieste su $30 \%$ sacharozès nustatytas $10,7 \%$, o su tuo pačiu kiekiu gliukozès - 41,3\% mažesnis nei sviesto be priedų, laikant mėginius 30 dienų $28{ }^{\circ} \mathrm{C}$ temperatūroje. Efektyviausias buvo sorbitolis, kuris 65,3\% sumažino peroksidų susidarymą 30 dienų laikotarpiu. Analogišku aktyvumu pasižymejjo ir vanilino priedas. Eksperimentas parodè, kad angliavandenių poveikis peroksidų susidarymui priklauso nuo peroksidų kiekio produkte, didèjant peroksidų kiekiui, slopinantis poveikis mažeja arba visiškai išnyksta.

Reikšminiai žodžiai: maisto priedai, kokybè, peroksidai, angliavandeniai, vanilinas. 